\title{
A new species of Newportia Gervais, I 847 from Puerto Rico, with a revised key to the species of the genus (Chilopoda, Scolopendromorpha, Scolopocryptopidae)
}

\author{
Arkady A. Schileyko ${ }^{1, \dagger}$ \\ I Zoological Museum of Moscow State Lomonosov University, Bolshaja Nikitskaja Str.6, 103009, Moscow, Russia \\ † urn:lsid:zoobank.org:author:9C7AC790-185C-46A0-B560-8B133B2FF14C \\ Corresponding author: Arkady A. Schileyko (schileyko1965@mail.ru)
}

Academic editor: P. Stoev | Received 5 February 2012 | Accepted 6 February 2013 | Published 8 March 2013

urn:lsid:zoobank.org:pub:47BC3926-D114-4F2E-9EAA-B3A15E9C2C6E

Citation: Schileyko AA (2013) A new species of Newportia Gervais, 1847 from Puerto Rico, with a revised key to the species of the genus (Chilopoda, Scolopendromorpha, Scolopocryptopidae). ZooKeys 276: 39-54. doi: 10.3897/ zookeys. 276.4876

\begin{abstract}
A new species of the centipede genus Newportia, N. stoevi sp. n., is described from Rio Encantado Cave, Puerto Rico. It differs from all congeners by having sternites distinctly margined laterally and ultimate legs bearing 4 spinous processes on both prefemur and femur, and 2 on tibia. The value of some terms used in the taxonomy of the genus have been analyzed and an amended identification key to the species of Newportia is provided.
\end{abstract}

\section{Keywords}

Newportia, Newportiinae, new species, identification key, external characters

\section{Introduction}

The genus Newportia Gervais, 1847 is still poorly known. It is especially so with regards to the Puerto Rican fauna where only two species have hitherto been registered. Silvestri (1908) reported N. ernsti Pocock, 1891 from Coamo Springs, while Chagas and Shelley (2003) recorded $N$. heteropoda Chamberlin, 1918 from two localities -8.4 mi (13.4 km) SW Luquillo, trail to Minas Falls off hwy. 191, Luquillo Division, Carib-

Copyright Arkady A. Schileyko. This is an open access article distributed under the terms of the Creative Commons Attribution License 3.0 (CC-BY), which permits unrestricted use, distribution, and reproduction in any medium, provided the original author and source are credited. 
bean National Forest and from $4 \mathrm{mi}(6.4 \mathrm{~km})$ N Villalba, Dona Juaña Recreation Area. To these should be added Chamberlin's (1950) uncertain record of Newportia sp. from Maricao Insular Forest, based on a specimen with missing ultimate legs.

Herewith, I describe a new species of Newportia recently collected in Puerto Rico by Dr Petar Beron from the National Museum of Natural History, Sofia (NMNHS). The specimen was assigned to Newportia and tentatively identified as a new species by Dr Pavel Stoev, curator of Myriapoda at the NMNHS who committed it for further study to me. This specimen differs from all congeners, in the first place, by important traits of the ultimate legs (which are normally developed and have no traces of regeneration) and unusually developed lateral margination of sternites.

The identification key to the species of Newportia (Schileyko and Minelli 1998) has been updated to accommodate this and other new species described recently (e.g., Newportia troglobia Chagas \& Shelley, 2003), as well as to reflect other nomenclature novelties proposed in the genus. Some general notes on the external anatomy of $\mathrm{New}$ portia have been made, too. The terminology follows Bonato et al. (2010).

\section{Systematic part}

SCOLOPENDROMORPHA Pocock, 1895

Scolopocryptopidae Pocock, 1896

Newportiinae Pocock, 1896

Newportia Gervais, 1847

\section{Newportia stoevi sp. $\mathrm{n}$.}

urn:Isid:zoobank.org:act:AE5E2F31-F3F2-45EB-9AD6-24EDA31D1D66

http://species-id.net/wiki/Newportia_stoevi

Figs $1-10$

Holotype: Puerto Rico, Florida Co., Rio Encantado Cave, 1 (sub?)adult, 29.07.2009, leg. P. Beron (NMNHS).

Locus typicus. Puerto Rico, Florida Co., Rio Encantado Cave.

Derivatio nominis: named after my friend and colleague Dr Pavel Stoev who drew my attention to this new species.

Diagnosis. Tergite 1 with rounded anterior transverse suture and incomplete paramedian sutures. Sternites distinctly margined laterally. Ultimate legs: prefemur with 4, femur with 3 small spinous processes medially and 1 ventrally; tibia with 2 small spinous processes medially. Tarsus 1 large and clavate (bulbous), clearly differing from the much thinner tarsus 2; the latter consisting of 19-20 articles.

Description. Length of body $c a 17 \mathrm{~mm}$, length of ultimate legs about $9 \mathrm{~mm}$. Color (in ethanol): entire animal uniformly light-yellow with cephalic plate and forcipular segment slightly darker (Fig. 1). Body sparsely pilose; sternites and legs less setose than tergites. 

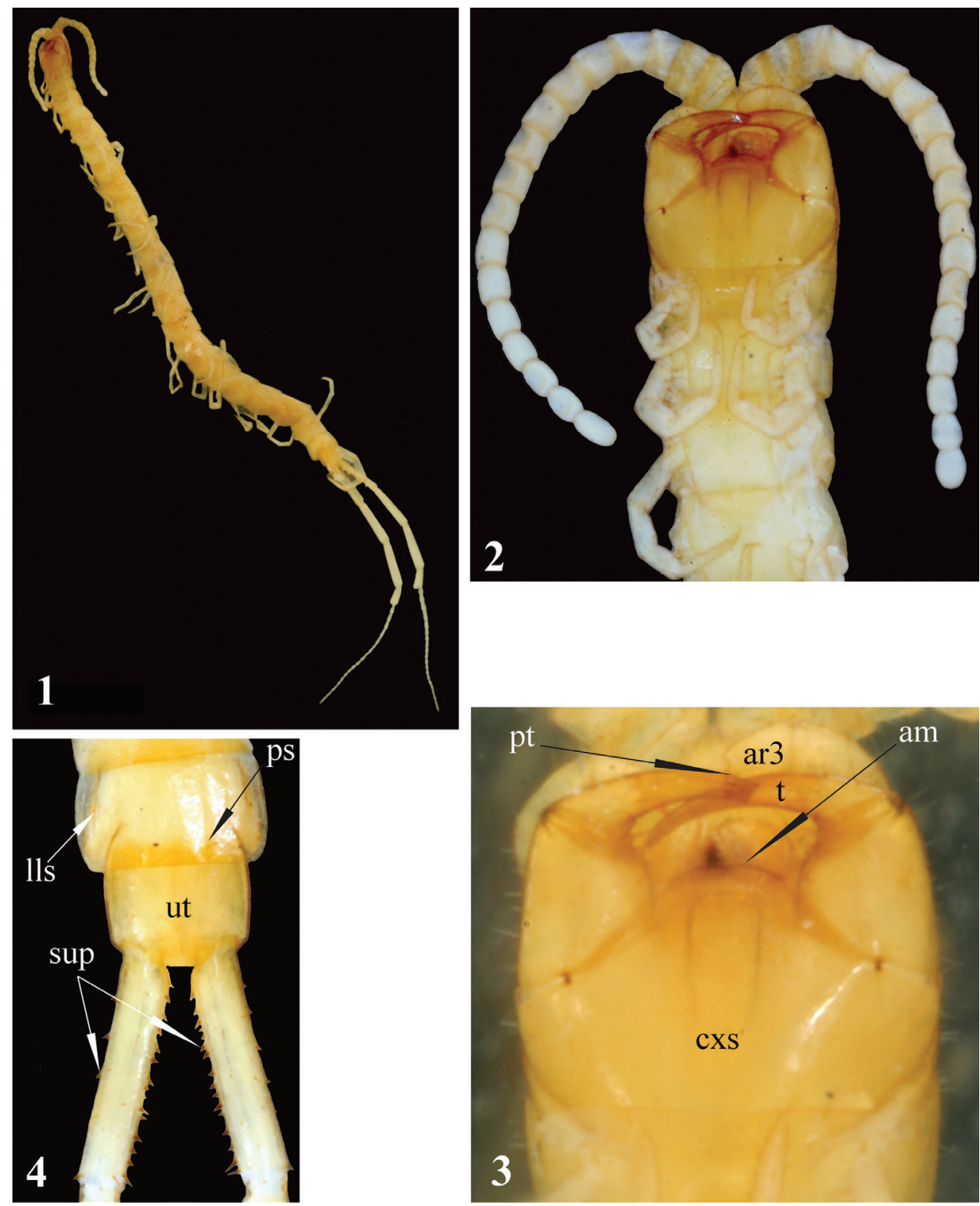

Figures I-4. Newportia stoevi, sp. n. I Habitus 2 Head and anterior segments, ventral view 3 Forcipular segment, ventral view 4 Tergites 22 and 23 and prefemora of ultimate legs, dorsal view; (pt) - pretarsus of second maxilla, (ar3) - article 3 of telopodite of second maxilla, (cxs) - forcipular coxosternite, (am) anterior margin of coxosternite, (t) - tarsungulum, (ps) - paramedian sutures, (lls) - lateral longitudinal sutures, (ut) - tergite of ultimate leg-bearing segment, (sup) - spurs of ultimate prefemur.

Antennae composed of 17 articles (Fig. 2), reaching rear edge of tergite 5 when folded backwards; 2.5 basal antennal articles covered by a few long setae, subsequent articles densely pilose. Basal antennal articles somewhat flattened dorso-ventrally. 
Head: cephalic plate visibly longer than wide, with rounded corners and very short paramedian sutures at posterior margin.

Second maxillae: as in all other Newportia species but dorsal spur on article 2 of the telopodite not recognisable. Pretarsus without spurs, with well-developed dorsal brush. The angle between the longitudinal axes of pretarsus and article 3 of telopodite slightly more than $100^{\circ}$ (Fig. 3), which is quite unusual condition in Scolopendromorpha.

Forcipular segment: coxosternite without any visible sutures (including the chitinlines). Anterior margin of coxosternite evidently convex (Fig. 3), divided by a median diastema into two low additionally sclerotised lobes; each lobe bearing a long seta. Trochanteroprefemoral process absent. Tarsungula normal.

Tergites: anterior margin of tergite 1 covered by the cephalic plate; tergite 1 with a rounded anterior transverse suture and paramedian sutures stretching from the transverse suture to the posterior tergal margin. Tergite 3 with a very characteristic thin oblique sutures bordering the anterior corners of tergite. Tergites 2-22 with complete paramedian sutures, tergites 3-21(22) with lateral longitudinal sutures (Fig. 4). Tergite 23 lacking sutures, its posterior margin convex. Tergite margination virtually absent, only tergite 23 distinctly margined laterally. Tergite 23 much wider rather than long and nearly rectangular in shape; its lateral sides slightly rounded (Fig. 4). All tergites without medial keel; pretergites also missing.

Sternites: trapeziform, 2-22 with incomplete (equally shortened from both sides) but with a well expressed median longitudinal sulcus. Sternites 2-21 with definite and complete lateral margination (Fig. 5) through lateral longitudinal sutures (see Remark 2); endosternites absent. Sternite 23 trapeziform, with a few very short (spur-like) setae on lateral sides (Fig. 6), with a straight posterior margin.

Legs: prefemur, femur and tibia with a few large setae (Fig. 5); tarsi with more numerous setae of various length and size. Tibia of legs $1-20$ with a lateral spur; both, ventral tibial spur and tarsal spur absent. Tarsi of legs 1-21 (Fig. 5) without distinct division between tarsus 1 and 2; pretarsi long, thin and sharply pointed. Pretarsi of legs 1-22 with two thin and long (as long as $1 / 2$ of pretarsus) accessory spines.

Coxopleuron (Figs 6,7): nearly completely pierced with coxal pores of various size - only coxopleural process and a narrow area bordering posterior margin of coxopleuron remaining poreless. Coxopleural process (Figs 6, 7) as long as ultimate sternite, conical, without additional spines. Coxopleural surface without setae. Posterior margin of pleuron of ultimate leg-bearing segment forming a very obtuse angle.

Ultimate legs (Fig. 8): slender, ca $9 \mathrm{~mm}$ long, width of prefemur $c a 0.5 \mathrm{~mm}$. Prefemur triangular in cross-section, with a standard row of 4 ventral spinous processes (Fig. 7), some spurs (strong, spine-like setae of various length) dorso-laterally and more numerous similar spurs dorso-medially (Fig. 4). All four prefemoral ventral spinous processes are of the same size, apically curved and ending in a pointed harpoon-like tip, which is accompanied by a long seta. Femur cylindrical, with 3 small spinous processes medially (Fig. 9) and 1 ventrally in the middle of femur (Fig. 10). Tibia cylindrical, with 2 small spinous processes medially: one close to its base and another at mid length (Figs 9, 10). Both femoral and tibial spinous processes are ac- 

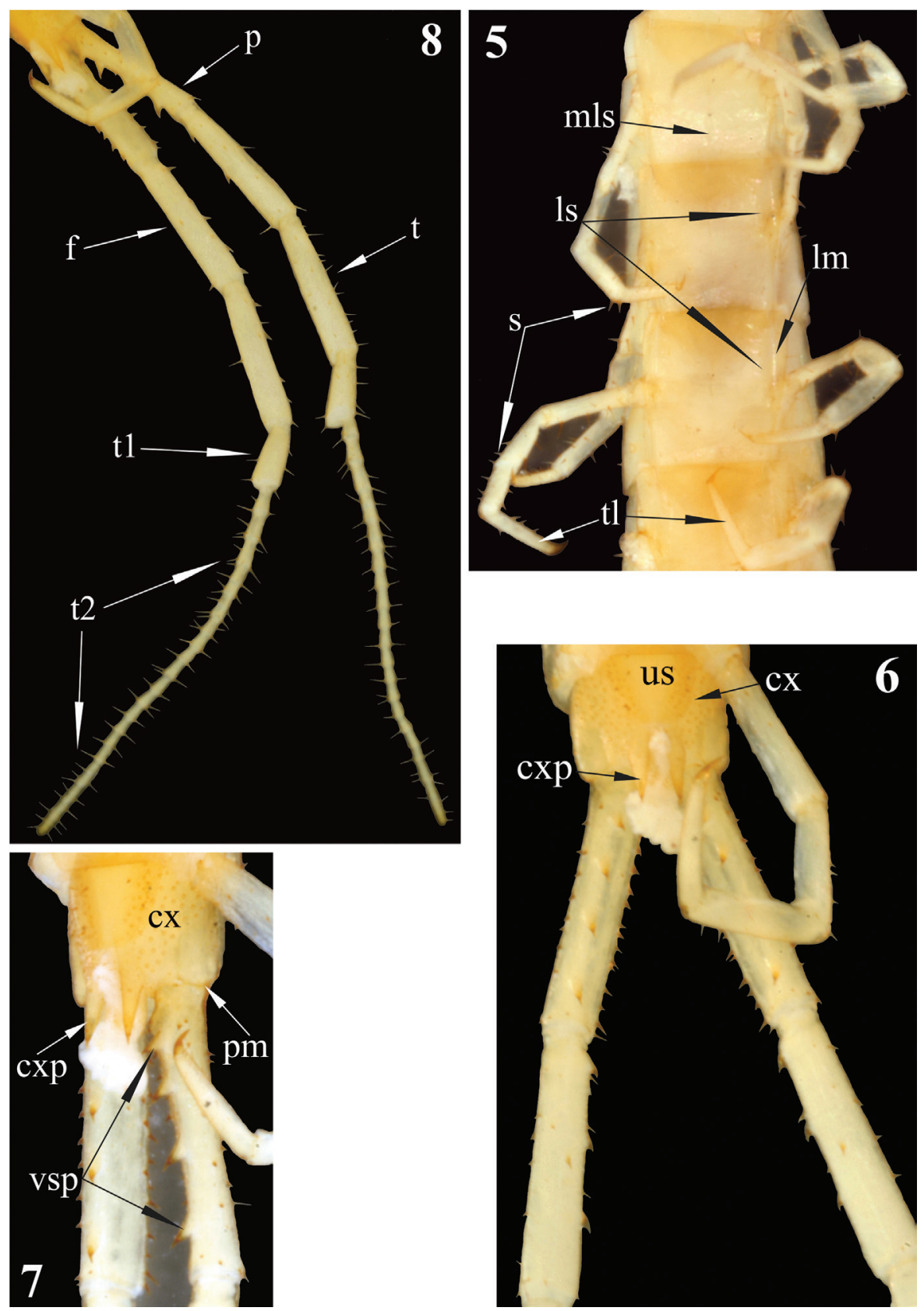

Figures 5-8. Newportia stoevi, sp. n. 5 Segments and midbody legs, ventral view 6 Posterior body end, ventral view 7 Left side of ultimate leg-bearing segment and prefemora of ultimate legs, ventro-lateral view 8 Ultimate legs, ventro-lateral view; (mls) - median longitudinal sulcus, (ls) - lateral sutures, (lm) lateral margination, (s) - setae, (tl) - monoarticulated tarsus of locomotory leg, (us) - sternite of ultimate leg-bearing segment, $(\mathbf{c x})$ - coxopleuron, $(\mathbf{c x p})$ - coxopleural process, $(\mathbf{p m})$ - posterior margin of pleuron of ultimate leg-bearing segment, (vsp) - ventral spinous processes of ultimate prefemur, $(\mathbf{p})$ - prefemur, (f) - femur, (t) - tibia, $(\mathbf{t} 1)-$ tarsus $1,(\mathbf{t} 2)-$ tarsus 2 . 

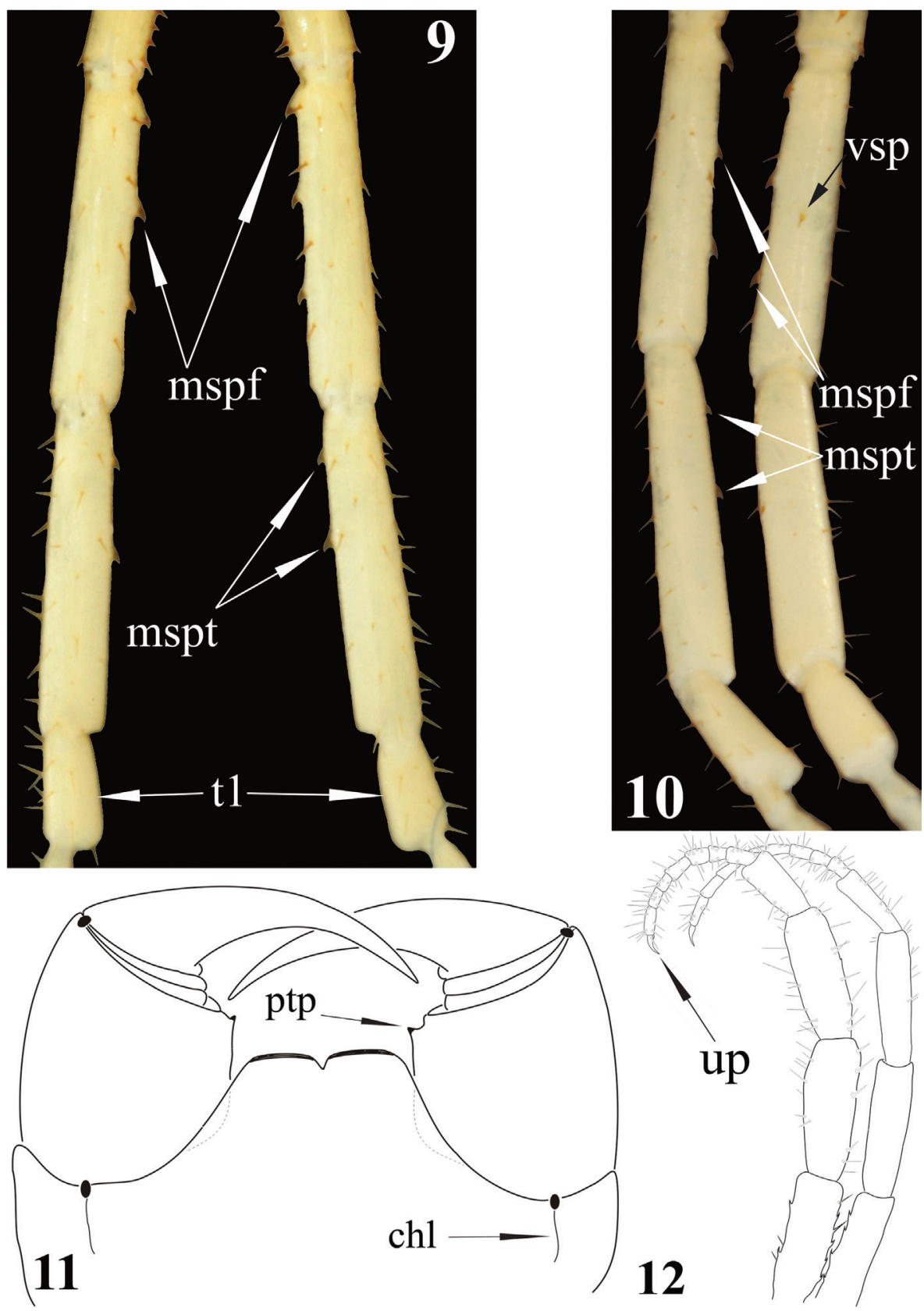

Figures 9-12. Newportia stoevi, sp. n. 9 Femora, tibiae and tarsi 1 of ultimate legs, dorsal view 10 Femora, tibiae and tarsi 1 of ultimate legs, ventral view; Newportia divergens Chamberlin, 1922 I I Forcipular segment, ventral view (after Schileyko and Minelli 1998); Newportia unguifer Chamberlin, 1921 I 2 Ultimate legs, dorso-lateral view (after Schileyko and Minelli 1998); (mspf) - medial spinous processes of ultimate femur, (mspt) - medial spinous processes of ultimate tibia, (vsp) - ventral spinous process of ultimate femur, (t1) - tarsus 1, (up) - ultimate pretarsus, (chl) - chitin-lines, (ptp) - process of trochanteroprefemur. 
companied by a single long ventral seta. Tibia practically as long as prefemur or femur. Tarsus well divided into tarsus 1 and tarsus 2 (Fig. 8), former as long as 1/2 of tibia. Tarsus 1 (Figs 8-10) is enlarged and clavate (bulbous); tarsus 2 thin, consisting of 19 (or 20) articles (Fig. 8). In a few places annulation of tarsus 2 is somewhat vague; for example, the very long ultimate article seems to consist of two articles, which are not well divided. Ultimate legs without pretarsus.

Range. The species is hitherto known only from its type locality.

Habitat and associated fauna. Being -250 m deep and $16910 \mathrm{~m}$ long Rio Encantado is the deepest and the longest cave system in Puerto Rico. This system lies in the Tertiary limestone area which stretches along the northern coast of the island (Peck 1974). N. stoevi has been collected deep inside the cave, in the aphotoc zone and although apparent troglomorphic traits are lacking it may well represent a troglobite, as its congener from Sistema de Purificacion, Mexico, N. troglobia (Chagas and Shelley 2003). In the cave it co-occurs with amblypigs, spiders, beetles (Dr. P. Beron, pers. comm.).

\section{Discussion}

1 This species is morphologically close to Newportia heteropoda Chamberlin, 1918 from which it can be readily distinguished by the following traits of the ultimate pair of legs: number of articles of tarsus 2 (19 vs. 9 in $N$. heteropoda); presence of 4 (vs. 3 in $N$. heteropoda) spinous processes on femur; presence of 2 (vs. 0 in $N$. heteropoda) such processes on tibia.

2 Schileyko (2009) wrote that in the family Scolopocryptopidae the lateral sternal sutures are known in Newportia, Tidops Chamberlin, 1915, Kartops Archey, 1923, Kethops Chamberlin, 1912 and Ectonocryptoides Shelley \& Mercurio, 2005. It should be noted, that Chagas (2011) considered Kartops as a junior synonym of Tidops. The lateral sternal sutures may be developed in various degrees (from complete to quite short), but only Kethops (see fig. 144 in Shelley 2002) and Ectonocryptoides sandrops Schileyko, 2009 have sterna with elevated lateral margins. However, in Newportia stoevi the lateral longitudinal sutures border the complete lateral margination, which seems to be considerably elevated over the surface of sternite.

3 Some groups of scolopendromorphs (the majority of Scolopendrinae, Otostigminae, Scolopocryptopinae and Plutoniumidae) have a well-developed, strongly sclerotized disto-medial projection of the forcipular trochanteroprefemur. Formerly, I used the term "forcipular median tooth" for it, but Bonato et al. (2010) proposed the term "process of trochanteroprefemur". The Newportiinae either entirely lack this process, or have it only as a small denticle (Fig. 11), similar to some geophilomorphs, for which Bonato et al. (2010) proposed the term 'distal denticles of trochanteroprefemur'.

4 As for the vague annulation of some articles of ultimate tarsus 2 in $N$. stoevi, I should mention that there are a few other species of Newportia in which this trait is observed, for example $N$. albana Chamberlin, 1957 and $N$. diagramma Cham- 
berlin, 1921 (see REMARKS to $N$. albana and Figure 5c of $N$. diagramma in Schileyko and Minelli 1998).

5 In some species of Newportia legs have one tarsal spur and two (lateral and ventral) tibial spurs, other species have one (lateral) tibial spur only (as N. stoevi) and in $N$. phoretha Chamberlin, 1950 spurs are entirely lacking (see p. 290 in Schileyko and Minelli 1998). In some species of Newportia (for example in N. longitarsis stechowi Verhoeff, 1938) lateral tibial spur is situated on an outgrowth of disto-lateral side of the tibia (see Fig. 2a in Schileyko and Minelli 1998). It is also worth mentioning that tibial spurs do not break off easily in Newportia as these spurs would do, for example, in Otostigmus. Absence of tibial spurs is another character that separates Ectonocryptopinae from Newportiinae.

\section{Identification key to the species of Newportia}

One of the main problems for identification of scolopendromorph centipedes is the high number of new species, described in the last decades that are still remaining outside the contemporary identification keys. I suggest that every description of new species in large genera (like Newportia) to be accompanied by the respective update of the available identification key. In cases where the genus includes just a few species, the identification key should be completely re-written.

The most recent key to the species of Newportia was provided by Schileyko and Minelli (1998). Since then several new species have been described by González-Sponga $(1997,2000)$ and Chagas and Shelley (2003) from Venezuela and Mexico, respectively. The latter authors have also revived $N$. azteca Humbert \& Saussure, 1869, although in the same paper they also stated (pp. 13-14): "We ... do not think that any conclusion [about the validity of azteca] can be reached". In 1998 Schileyko and Minelli wrote (p. 291): "Another nominal taxon very similar if not identical to $N$. oriena and N. spinipes seems to be $N$. azteca Humbert \& Saussure, 1869: 158 [cf. Attems, 1930: 275] whose true identity, however, remains to us as doubtful as it was to Attems [1930]". However, Chagas and Shelley (2003) were absolutely correct when writing (p. 13) that N. azteca is the third oldest name in Newportia (after $N$. longitarsis and $N$. mexicana) and in case of synonymy would have priority by 27 years over $N$. spinipes. Since there is no available characters at the moment to separate these two species I put them together in the following identification key. Both, $N$. stoevi sp. n. and N. troglobia, are included in the key provided below. With regards to the seventeen new species of Newportia described from Venezuela by González-Sponga $(1997,2000)$, they will be analyzed in a paper dedicated to the scolopendromorph fauna of Venezuela that is currently in progress.

1 Tarsus 2 of ultimate legs clearly divided into distinct articles

- $\quad$ Tarsus 2 of ultimate legs undivided

2 Ultimate leg with a well-developed (claw-shaped) pretarsus which is as long as, or longer than half of the ultimate article of tarsus 2 (Fig. 12) ..... N. unguifer 
Ultimate leg without a well-developed pretarsus 3 Tergite 1 without an anterior transverse suture. N. sargenti Tergite 1 with an anterior transverse suture Tergite 1 with a rounded anterior transverse suture and, generally, with paramedian sutures which do not form a "W" just behind the anterior transverse suture; in a few species these sutures are absent or extremely short (Fig. 13) ...5 Tergite 1 with an anterior transverse suture in the form of a very obtuse angle and with paramedian sutures forked anteriorly, thus forming a "W" just be-

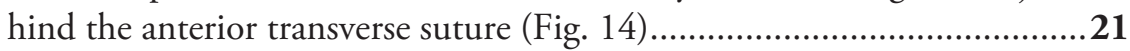
Some pairs of legs, usually 2(4)-(19)20, with tibial spurs ...........................6 Tibial spurs missing on all legs. N. phoretha Femur of ultimate legs without spinous processes ........................................ Femur of ultimate legs with spinous processes Tergite 1 with rudimentary paramedian sutures (Fig. 13) or sutures completely lacking. N. pusilla Paramedian sutures of tergite 1 half-complete or complete, sometimes shortly interrupted in the middle. Coxopleural process extremely short; tergite 1 with poorly developed paramedian sutures (Fig. 15) which cross the anterior transverse suture.... N. diagramma Coxopleural process normal (Fig. 7); tergite 1 with well-developed paramedian sutures stretching between anterior transverse suture and posterior tergal margin

Tarsus 2 of ultimate legs composed of 19-25 articles................ N. aureana Tarsus 2 of ultimate legs composed of 6-7 articles... N. longitarsis tropicalis Tibiae 2-20 with lateral and ventral spurs ................................................11 Tibiae 2-20 with a lateral spur only 12 Femur of ultimate legs with 1(-2) ventral spinous process(es) ....... N. cubana Femur of ultimate legs with 2-3 medial spinous processes.

N. longitarsis virginensis Tarsus 2 of ultimate legs composed of 4 articles; tarsus 1 almost as long as the tibia N. dentata Tarsus 2 of ultimate legs composed of 7-26 articles; tarsus 1 quite shorter than the tibia

Tarsus 2 of ultimate legs composed of 26 articles; cephalic plate without paramedian sutures

N. leptotarsis

Tarsus 2 of ultimate legs composed of 7-20 articles; cephalic plate often with incomplete paramedian sutures.

Anterior ends of the half-complete paramedian sutures of tergite 1 very shortly bifurcate behind the anterior transverse suture (Fig. 16). N. oligopla Paramedian sutures of tergite 1 from absent to complete, never bifurcated anteriorly Tarsus of ultimate legs uniformly divided, without distinction into tarsus 1 and tarsus 2 

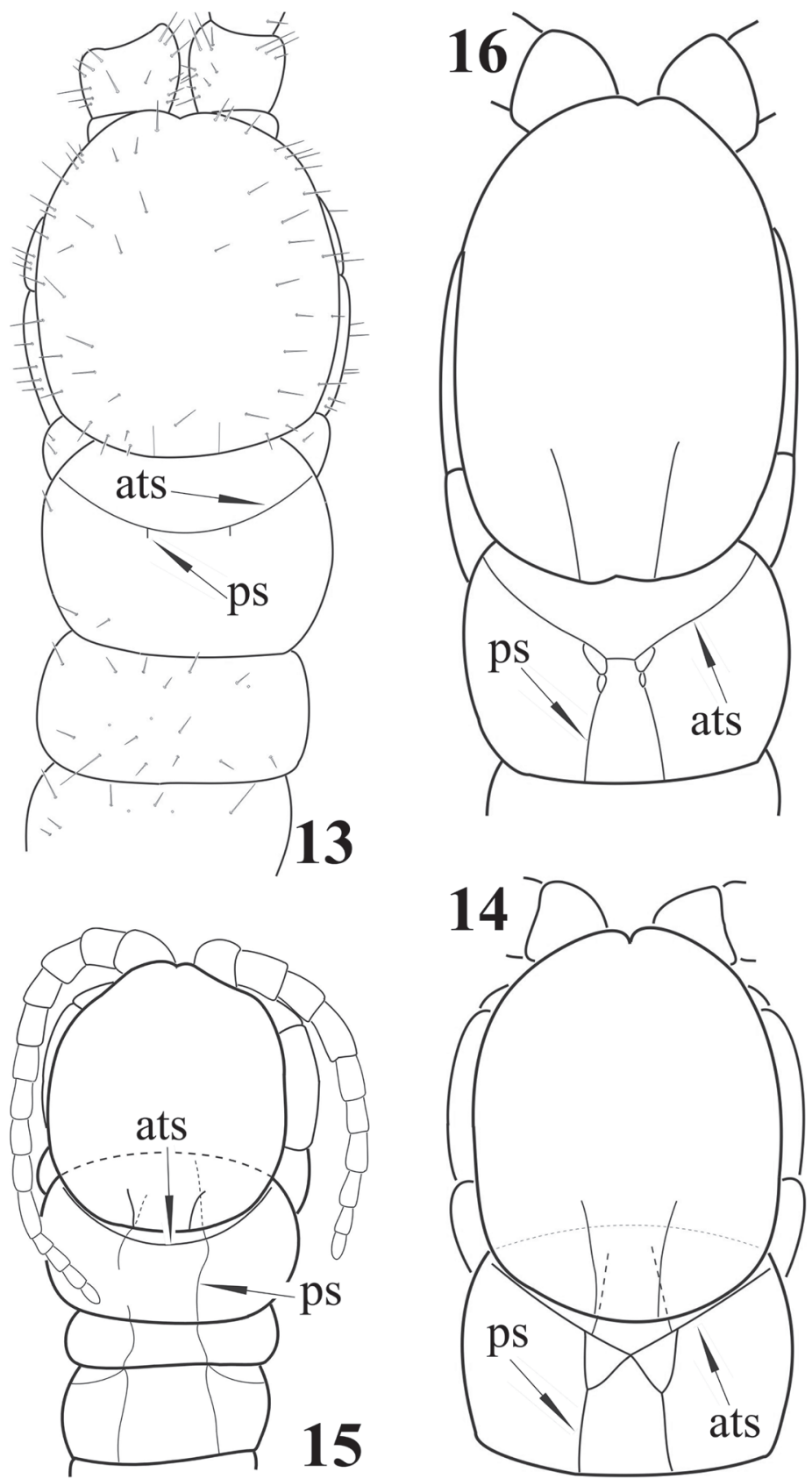

Figures 13-16. Newportia sp. 13 Cephalic plate and tergites 1-3, dorsal view (after Schileyko and Minelli 1998, re-drawn); Newportia ignorata Kraus, 1955 I 4 Cephalic plate and tergite 1, dorsal view (after Schileyko and Minelli 1998); Newportia diagramma Chamberlin, 1921 I 5 Cephalic plate and tergites 1-3, dorsal view (after Schileyko and Minelli 1998); Newportia oligopla Chamberlin, 1945 I 6 Cephalic plate and tergite 1, dorsal view (after Chamberlin 1945, re-drawn); (ats) - anterior transverse suture, (ps) - paramedian suture. 
Tarsus of ultimate legs distinctly divided into tarsus 1 and tarsus $2 \ldots \ldots \ldots . .16$

17 Femur of ultimate legs with 3 spinous processes, tibia without spinous processes and tarsus 2 composed of 9 articles N. heteropoda Femur of ultimate legs with 4 spinous processes, tibia with 2 spinous processes (Figs 9, 10) tarsus 2 of 19 articles (Fig. 8) .......Newportia stoevi sp. $\mathbf{n}$. Tergite 1 with complete paramedian sutures which cross the anterior transverse suture. ... longitarsis longitarsis

Tergite 1 with incomplete paramedian sutures of various length, from halfcomplete (Fig. 17) to rudimentary (Fig. 13), running between the posterior tergal margin and the anterior transverse suture; rarely without any trace of paramedian sutures

19 Cephalic plate with a thin transverse suture which crosses the short paramedian sutures close to the posterior margin of the cephalic plate ...N. longitarsis sylvae Cephalic plate without any transverse suture Prefemur of ultimate legs with 3 large ventral spinous processes

\section{N. longitarsis guadeloupensis}

Prefemur of ultimate legs with 4 large ventral spinous processes

\section{N. longitarsis stechowi}

Tarsus 2 of ultimate legs composed of 39-40 articles

N. sabina

Tarsus 2 of ultimate legs composed of less than 30 articles. Legs without tarsal spurs; tibia of ultimate legs shorter or as long as femur26 Outer branches of forked paramedian sutures of tergite 1 extending in front of the anterior transverse suture up to the anterior border of this tergite

N. spinipes $+N$. azteca

Forked paramedian sutures of tergite 1 ending up in the anterior transverse suture.

Tarsus 2 of ultimate legs consists of 11-12 articles, prefemur laterally with strong setae.

N. atoyaca

Tarsus 2 of ultimate legs consists of $5-8$ articles, prefemur laterally with small spines

Tarsus 1 and tarsus 2 of ultimate legs with different shapes (Fig. 19) ........29 Tergite 1 with paramedian sutures in front of the anterior transverse suture (Fig. 14); tibia of ultimate legs cylindrical, tarsus composed of 7-9 articles (Fig. 18)

- $\quad$ Tergite 1 without paramedian sutures in front of the anterior transverse suture; tibia of ultimate legs distinctly claviform distally (Fig. 20), tarsus composed of ca. 15 articles (N. weyrauchi). 

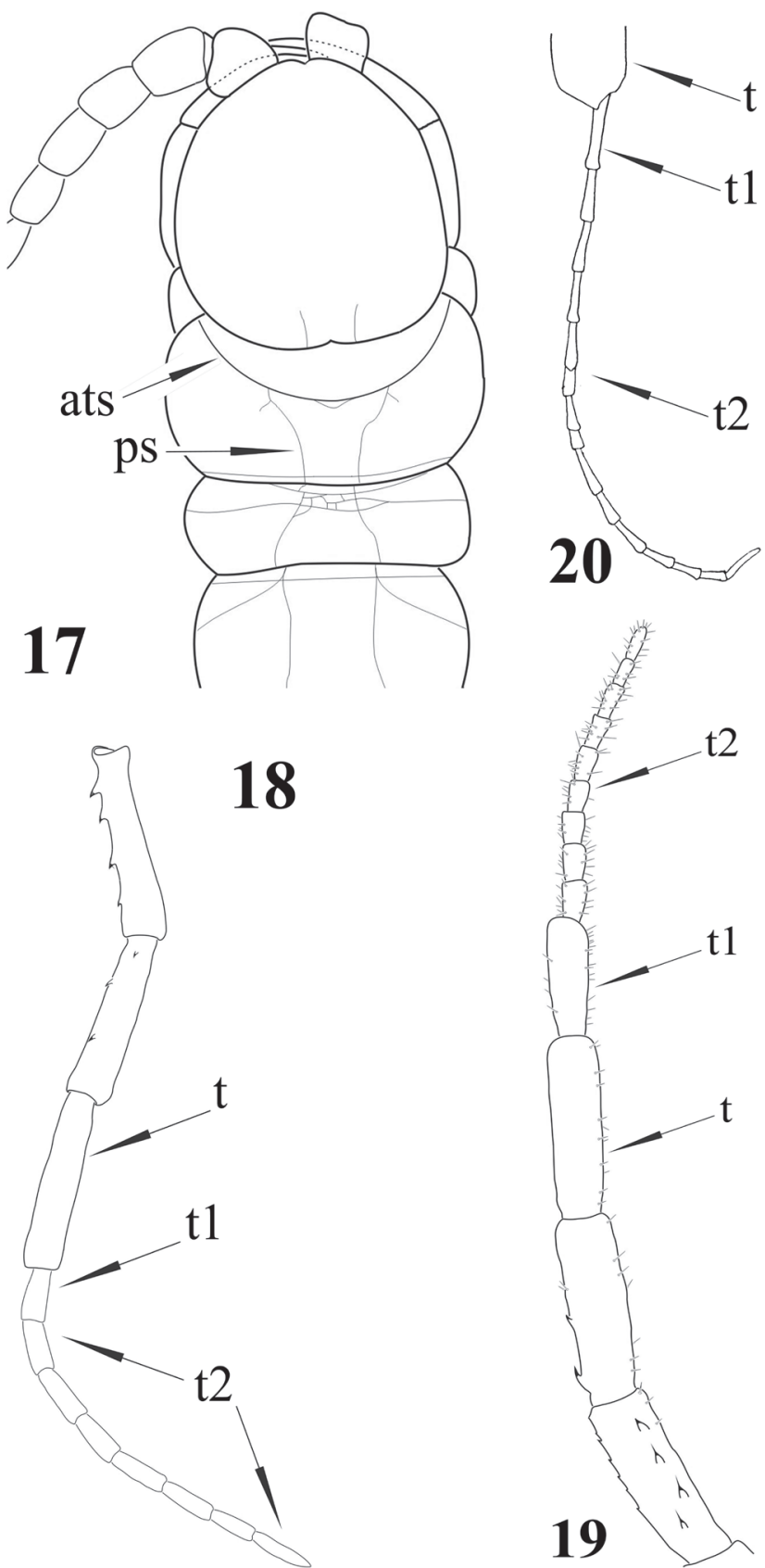

Figures 17-20. Newportia adisi Schileyko \& Minelli, 1998 I7 Cephalic plate and tergites 1-3, dorsal view (after Schileyko and Minelli 1998); Newportia ignorata Kraus, 1955 I 8 Right ultimate leg, medially (after Schileyko and Minelli 1998); Newportia monticola Pocock, 189019 Right ultimate leg, ventral view (after Schileyko and Minelli 1998); Newportia weyrauchi Chamberlin, 195520 Ultimate leg: distal portion of tibia and tarsus, ventral view (after Chamberlin 1955); (ats) - anterior transverse suture, (ps) - paramedian suture, $(\mathbf{t})$ - tibia, $(\mathbf{t} 1)-\operatorname{tarsus} 1,(\mathbf{t} 2)-\operatorname{tarsus} 2$. 
Prefemur of ultimate legs with 4 ventral spinous processes .. N. w. weyrauchi Prefemur of ultimate legs with 3 ventral spinous processes .... N. w. thibaudi Outer branches of the forked paramedian sutures of tergite 1 crossing the anterior transverse suture (Fig. 14) and ending onto the tergal anterior margin...30 Forked paramedian sutures of tergite 1 ending in the anterior transverse suture

N. monticola

Femur of ultimate legs medially with one basal and one distal spinous processes, ventrally without them. Sternites 2-12(15) each with a median longitudinal sulcus.

N. fubrmanni

Femur of ultimate legs medially with one basal spinous process, ventrally with 1-2 such processes. Sternites 2-19 each with a median longitudinal sulcus

N. simoni

Ultimate legs with a well-developed claw-shaped pretarsus (which is as long as the poorly distinct ultimate article of tarsus 2)

N. amazonica

Ultimate legs normally without claw-shaped pretarsus (if a small ultimate claw is present, then it is less than half as long as the poorly distinct ultimate article of tarsus 2)

Tibia of ultimate legs with 3 ventral spinous processes; medial spinous processes of prefemur almost as large as the ventral ones

N. mexicana

Tibia of ultimate legs without spinous processes, medial spinous processes of prefemur (when present) considerably smaller than the large ventral ones... 33 Tergite 1 with rounded anterior transverse suture and with or without paramedian sutures

Tergite 1 with anterior transverse suture angulated caudad to midline and giving rise to short longitudinal suture, which bifurcate caudally (fig. 1 in Chagas \& Shelley, 2003)

N. troglobia

34 Tergite 1 without paramedian sutures between its posterior margin and the anterior transverse suture, rarely with very short tracks just behind the anterior transverse suture (Fig. 13)

Tergite 1 with complete (more rarely half-complete) paramedian sutures....37 Paramedian sutures of cephalic plate very short. Forcipular coxosternite without median suture. Ultimate sternite without median longitudinal sulcus. Femur of ultimate legs with a row of 2-3 spinous processes Paramedian sutures of cephalic plate almost reaching its middle. Forcipular coxosternite with a well-developed median suture. Ultimate sternite with a clear median longitudinal sulcus or depression. Femur of ultimate legs without or with a single very small spinous process

N. maxima

36 Tarsus of ultimate legs uniform, without distinct division into tarsus 1 and 2. Forcipular trochanteroprefemur without process N. lasia Tarsus of ultimate legs distinctly divided into a shorter tarsus 1 and a longer tarsus 2 (Fig. 21). Forcipular trochanteroprefemur with a process .......N. patavina Paramedian sutures of tergite 1 not bifurcate 38 Paramedian sutures of tergite 1 bifurcate 

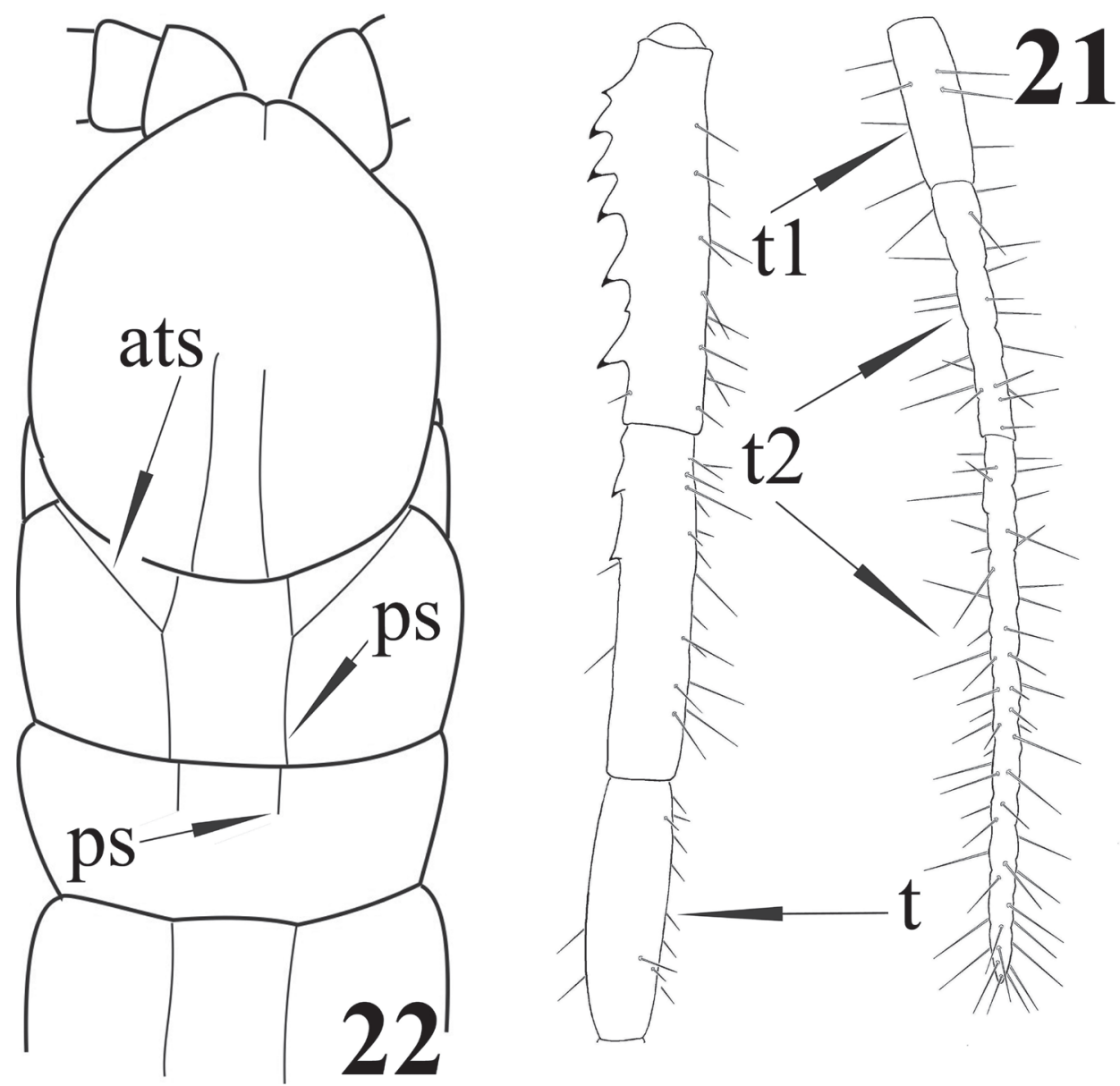

Figures 21, 22. Newportia patavina Schileyko \& Minelli, 1998 2I Right ultimate leg, medially (after Schileyko and Minelli 1998); Newportia divergens Chamberlin, 192222 Cephalic plate and tergites 1-3, dorsal view (after Chamberlin 1922, re-drawn); (ats) - anterior transverse suture, (ps) - paramedian suture, $(\mathbf{t})$ - tibia, $(\mathbf{t} 1)-$ tarsus $1,(\mathbf{t} 2)-\operatorname{tarsus} 2$.

38 Anterior transverse suture of tergite 1 interrupted between the paramedian sutures (Fig. 22).

- $\quad$ Tergite 1 with a complete anterior transverse suture (Figs 15, 17) ............39

39 Tarsus of ultimate legs uniform

N. brevipes

Tarsus 1 of ultimate legs abruptly differing from the tarsus 2

40

40 Cephalic plate with a transverse suture crossing the paramedian sutures near the posterior margin (N. ernsti)

- $\quad$ Cephalic plate without transverse suture (Fig. 13)

41 Prefemur of ultimate legs with 6 (rarely 7) ventral spinous processes. Transverse suture of cephalic plate very distinct 
- $\quad$ Prefemur of ultimate legs with 5 ventral spinous processes. Cephalic plate: median part of transverse suture between the paramedian sutures often poorly visible N. e. fossulata

42 Paramedian sutures of tergite 1 ending up in the anterior transverse suture; tergite 2 with complete paramedian sutures

N. bielawskii

- $\quad$ Paramedian sutures of tergite 1 complete, crossing the anterior transverse suture; tergite 2 with short paramedian sutures or sutures totally missing .......43

43 Tergite 2 without paramedian sutures (these begin from tergite 5-6 onwards); four basal articles of tarsus 2 of ultimate legs definitely separated from each other (fig. 9 in Chamberlin 1957)

N. albana

- $\quad$ Tergite 2 with shortened paramedian sutures (Fig. 22); all articles of tarsus 2 of ultimate legs not well separated..............................................................44

44 All legs with a tarsal spur and both lateral and ventral tibial spurs ..... N. stolli All legs with a lateral tibial spur only.....

N. paraensis

\section{Acknowledgements}

I am very grateful to Prof. Dr. Alessandro Minelli, Dr. Amazonas Chagas-Jr. and Dr. John Lewis for their valuable comments and constructive criticism that helped me improve the quality of the paper. My sincerest thanks also to my father, Prof. Dr. Anatoly A. Schileyko (Moscow Institute of Problems of Evolutionary Morphology and Ecology of Animals), for correcting the English of the earlier version of the manuscript. I would also like to thank Dr. Pavel Stoev for his invaluable support during the preparation of the paper. Open access to this paper was supported by the Encyclopedia of Life (EOL) Open Access Support Project (EOASP).

\section{References}

Attems C (1930) Myriopoda. 2. Scolopendromorpha. Das Tierreich, 54. Walter de Gruyter, Berlin, 308 pp.

Bonato L, Edgecombe G, Lewis JGE, Minelli A, Pereira L, Shelley RM, Zapparoli M (2010) A common terminology for the external anatomy of centipedes (Chilopoda). Zookeys 69: 17-51. doi: 10.3897/zookeys.69.737

Chagas-Junior A (2011) A review of the centipede genus Tidops Chamberlin (Scolopendromorpha, Scolopocryptopidae, Newportiinae). International Journal of Myriapodology 5: 63-82. doi: 10.3897/ijm.5.1649

Chagas-Junior A, Shelley RM (2003) The centip ede genus Newportia Gervais, 1847, in Mexico: description of a new troglomorphic species; redescription of $N$. sabina Chamberlin, 1942; revival of N. azteca Humbert \& Saussure, 1869; and a summary of the fauna (Scolopendromorpha: Scolopocryptopidae: Newportiinae). Zootaxa 379: 1-20. 
Chamberlin RV (1922) Centipeds of Central America. Proceedings of the United States National Museum 60(7): 1-17.

Chamberlin RV (1945) Two new centipedes from Trinidad. Entomological News 56(7): 171-174.

Chamberlin RV (1950) Some chilopods from Puerto Rico. Proceedings of the Biological Society of Washington 63: 155-162.

Chamberlin RV (1955) The Chilopoda of the Lund University and California Academy of Science Expedition. Lunds universitets årsskrift 51(5): 1-61.

Chamberlin RV (1957) Scolopendrid chilopods of the Northern Andes region taken on the California Academy South America expedition of 1954-55. Great Basin Naturalist 17(1/2): 30-41.

González-Sponga MA (1997) Miriapodos de Venezuela. Siete nuevas especies del genero Newportia (Chilopoda: Scolopendromorpha: Cryptopidae). Memoria de la Sociedad de Ciencias Naturales La Salle 57(148): 33-47.

González-Sponga MA (2000) Miriapodos de Venezuela: diez nuevas especies del genero Newportia (Chilopoda: Scolopendromorpha: Cryptopidae). Memoria de la Fundación La Salle de Ciencias Naturales 60(153): 103-122.

Peck SB (1974) The Invertebrate Fauna of Tropical American Caves, Part II: Puerto Rico, An Ecological and Zoogeographic Analysis. Biotropica 6(1): 14-31. doi: 10.2307/2989693

Schileyko A (2009) Ectonocryptoides sandrops - a new scolopendromorph centipede from Belize. Soil organisms 81(3): 519-530.

Schileyko A, Minelli A (1998) On the genus Newportia. Arthropoda Selecta 7(4): 265-299.

Shelley RM (2002) A synopsis of the North American centipedes of the order Scolopendromorpha (Chilopoda). Virginia Museum of Natural History Memoir 5: 1-108.

Silvestri F (1908) Myriopoda from Porto Rico and Culebra. Bulletin of the American Museum of Natural History 24: 563-578. 